\title{
A TAMED HORNED LARK
}

\author{
MRS. PERCY DRURY, Maple Creek
}

When my daughter was coming home some years ago, during the last week of October, she picked up a Horned Lark that had apparently hit the barb-wire fence and fallen in the snow. We wrapped it in flannel and placed it in a box near the stove. Soon it revived. We fed it fine oatmeal and bread crumbs, keeping it in the house, as the ground was covered with snow and it was freezing every night.

We could see that one wing was hurt, and in about a week the rnd pinion fell off, so we knew it couldn't fly. We made a cage by putting wires across an apple box, and called him "Nick" because of his horns. He soon became tame and came when we called him. My daughter would say: "Have a fight", and poke her fingers at him as if pecking. $\mathrm{He}$ would ruffle up his feathers, jump up and down, and peck back. Then she would say: "Alright let's be friends" and he would lay his head against her hand with his feathers all down again - he seemed to know it was just a game.

He liked white cake and would take it from the hand to the back of his cage, but if he were offered a piece of bread he would just look at it and then at us, as if to say: "You can't fool me". During the five months he was with us we became very fond of him. Unfortunately he was killed by the cat. We really missed him and his cheery morning song. We were sorry that we couldn't turn him loose for we knew that he was unable to fly.

\section{A Sense of Reasoning}

\section{Jessie D. Greenbank, Kelso, Sask.}

Two years ago a pair of swallows were determined to build their nest on the wall, beneath the veranda roof, in spite of the fact that I kept tearing their nest down before it was completed, as they are not very clean birds to have nesting so near the house.

They rebuilt, going higher, until at last they were so close under the roof of the veranda that we wondered how their young could possibly manage to fly from the edge of the nest. To our amazement the parent birds built a small platform of mud and straw, plastered to the brick wall. Later we watched the young birds hop from the edge of their nest onto the platform, then to the telephone wires.

\section{Greatly Maligned}

\section{Jessie D. Greenbank, Kelso, Sask.}

We think that skunks are a greatly maligned animal, and that the good they do greatly offsets the few chickens they occasionally help themselves to. We have had whole families of them around, and never lost a chicken, but they certainly cleaned up the rats.

One night, last fall, we heard quite a commotion among the young chickens near the barn. My husband went down with flashlight and gun, prepared to find all the chickens slaughtered, but found that a large skunk had come out from under the chop house, where it had been after rats. It frightened the chickens but did no damage.

She sauntered nonchalantly into the barn, climbed up in a manger and went to sleep, curled up like a cat, not a bit perturbed by gun or flashlight.

\section{Whooping Cranes At $\$ 5$ Per Bird \\ (From the Saskatchewan News, published in Prince Albert)}

June 23, 1904-Whooping cranes, species of bird that is approaching extinction, were in ample supply 50 years ago as can be seen from the following advertisement which appeared in The Times: "I will pay $\$ 5$ for young and old Whooping Cranes (large ones) delivered in good shape at Edmonton, Alta., N.W.T. For further information apply to A. McCusker, Edmonton." 